\title{
Extreme Coexceedances in South Eastern European Stock Markets with Focus on EU Accession Countries
}

\author{
Asst. Prof. Dr. Dragan Tevdovski (Ss. Cyril and Methodius University, Macedonia)
}

\begin{abstract}
The aim of this paper is to investigate and document the financial contagion of the South Eastern Europe (SEE) stock markets. Using a modification of the Bae et al. (2003) coexceedance approach based on multinomial logistic regressions we model the occurrence of the large negative or positive stock returns on a given day across the SEE stock markets. Specifically, we divide the SEE stock markets on two groups based on country's EU membership in order to allow for transmission mechanism from major EU economies stock markets to EU member countries from SEE, and in addition, transitory effect from EU member countries from SEE to accession countries from SEE region. We test the persistence, asset class and volatility effects on the likelihood of the coexceedances in both SEE groups. We find that effects differ: (i) between negative and positive coexceedances and (ii) between the EU member countries and EU accession countries stock markets from SEE. The empirical evidence for the persistence effects, asset class and volatility effects in the SEE region should draw the attention of both investors and policy makers.
\end{abstract}

\section{Introduction}

The stock market comovements received a lot of attention in international finance since it has important practical implications for asset allocation and investment management. There is voluminous empirical literature that examines stock market comovements among developed countries (for example, Engle and Susmel (1993), Bekaert and Harvey (1995), Longin and Solnik (1995), Forbes and Rigobon (2002) and Johnson and Soenen (2003). Also, there is increasing body of literature concerning Central and Eastern Europe (CEE) stock market comovements (for example, Kasch-Haroutounian and Price (2001), Voronkova (2004), Cappieollo, et al. (2006), Babetskii et al. (2007), Egert and Kocenda (2007), Cerny and Koblas (2008), Gilmore et al. (2008) and Kocenda and Egert (2011). However, the stock markets comovements in South Eastern Europe (SEE) have been analyzed rather rarely.

Kenourgios and Samitas (2011) examine long-run relationships among five Balkan emerging stock markets (Turkey, Romania, Bulgaria, Croatia, Serbia), the United States and three developed European markets (UK, Germany, Greece), during the period 2000-2009. Using conventional and regime-switching cointegration tests and Monte Carlo simulation, the results provide an evidence in favour of a long-run cointegrating relationship between the Balkan emerging markets within the region and globally. Gradojevic and Dobardzic (2012) employ frequency domain approach to analyze the causal relationship between the returns on main indexes of Croatia, Slovenia, Hungary and Germany on the return of the major Serbian stock exchange index. The results found evidence of a somewhat dominant effect of the Croatian and Slovenian stock exchange indexes on Serbian stock index across a range of frequencies. Horvath and Petrovski (2013) examine the international stock market comovements between Western Europe vis-àvis Central (the Czech Republic, Hungary and Poland) and South Eastern Europe (Croatia, Macedonia and Serbia) using multivariate GARCH models in 2006-2011. The results indicate that the degree of comovements is much higher for Central Europe.

In this paper, we use method proposed by Bae et al. (2003) to investigate the comovements in the extreme returns between SEE stock markets. Extreme returns in one country, or exceedances, are large positive and large negative returns only in that country. Coexceedances are the joint occurrences of extreme returns in different countries. We divide the SEE countries on two groups: EU accession countries and EU member countries and use the multinomial logit model to explain the coexceedances that occurs in each group. Specifically, we allow transitory effects from major EU economies stock markets to EU member countries from SEE, and in addition, transitory effects from EU member countries from SEE to accession countries from SEE region. Following Christiansen \& Ranaldo (2009) we test the persistence effects, asset class effects and volatility effects on the likelihood of the coexceedances in each SEE groups. Persistence effects refer to the likelihood of observing autocorrelation in the coexceedances, i.e. whether the extreme stock returns are followed by subsequent movements in the same direction or in the opposite direction. The asset class effects test the explanation power of the three asset class groups, namely interest rates, currency returns and stock returns, for extreme stock returns. Finally, the volatility effects refer to the link between extreme stock returns and volatility in interest rates, currency returns and stock returns.

We find strong persistence effects in the both SEE groups (EU member states and EU accession countries). The extreme stock returns are characterized with subsequent movement in same direction. The coexceedances in EU member countries from SEE stock markets are influenced by the coexceedances in major EU economies stock markets, while in the case of EU accession countries from SEE stock markets this influence is much weaker and present only for positive coexceedances. However, negative coexceedances of accession countries 
from SEE are influenced by negative coexceedances from EU member countries from SEE stock markets, which imply that in the accession group stock markets bad signals comes from region, while good signals comes from the major EU economies. In respect to asset class effects and volatility effects, the results suggest that later have more influence on extreme coexceedance on the SEE stock markets than the former. The volatility of the observed stock markets is important in determination of the extreme returns comovement in the both group of SEE markets.

The results of this study may help policy makers to understand the nature of cross-region shock transmission. Similarly, it may be useful to investment managers for international portfolio diversification.

The structure of the remaining part of the paper is as follows: In Section 2 we present the data and in Section 3 we explain methodological framework. Section 4 contains the empirical results, and Section 5 concludes.

\section{Data Description}

We consider three groups of countries, while each is consisted of five countries. The first two groups are SEE groups. The criterion for division is the EU membership. The first is the group of EU accession countries from SEE: Bosnia and Herzegovina, Macedonia, Montenegro, Serbia and Turkey. Albania and Kosovo are not included due data availability. The second is the group of EU member countries from SEE: Greece, Slovenia, Romania, Bulgaria and Croatia. Greece and Slovenia were EU members during total sample period, while the rest of the countries only the part of the sample period. However, in the models we use dummy variables to capture effect of January 1, 2007, when majority of the countries in this group are EU members. The group of major EU economies, according to nominal GDP in 2012, consists of the following countries: Germany, United Kingdom, France, Italy and Spain.

We apply the daily data from DataStream stock index for various countries. Only in the cases of Bosnia and Herzegovina, Croatia, Macedonia, Montenegro and Serbia, we use the relevant index from the local stock market (SASX10, CROBEX, MBI10, MONEX20 and BELEXline), because the DataStream stock index is not available.

We use daily log returns calculated from the price indexes for the stock markets measured in the local currency. Christiansen \& Ranaldo (2009) argue that local currency returns are equivalent to currency hedged returns, while using common currency returns would bias the results and confound the genuine stock performance with that of the exchange rates. The data covers the period from October 4, 2004 to November 13, 2013. It gives a total of 2378 observations and covers both bull and bear phases, high and low volatility and different market conditions.

\subsection{Coexceedance Variables}

We focus on occurrences of extreme returns. We arbitrarily define a negative (positive) extreme return, or negative (positive) exceedance, as one that lies below (above) the 10\% (90\%) percentile of the marginal return distribution. We treat extreme negative and extreme positive returns separately.

Following Christiansen \& Ranaldo (2009) we construct a variable that counts the number of extreme negative returns for EU accession countries from SEE on a given day. The variable can take on integer values between 0 and 5. We collect observations of 2 and above into one group, so the variable is truncated to take on values between 0 and 2. We denote this variable the negative coexceedance variable for the EU accession countries group. So, we distinguish between following situations for a given day: no extreme return, only one country with an extreme return, and several countries with an extreme return. A similar negative coexceedance variables are constructed for the group of EU member countries from SEE and group of major EU economies. The positive coexceedance variable for the EU accession countries is constructed by counting the number of positive extreme returns on the EU accession stock markets on a given day. Finally, we construct the positive coexceedance variables for the group of EU member countries from SEE and group of major EU economies. We use the following notation for the coexceedance variables:

- $X N_{t}^{A C C}$ : negative coexceedance for EU accession countries from SEE on day $t$.

- $X P_{t}^{A C C}$ : positive coexceedance for EU accession countries from SEE on day $t$.

- $X N_{t}^{E U S}$ : negative coexceedance for EU member countries from SEE on day $t$.

- $X P_{t}^{E U S}$ : positive coexceedance for EU member countries from SEE on day $t$.

- $X N_{t}^{M E U}$ : negative coexceedance for major EU economies on day $t$.

- $X P_{t}^{M E U}$ : positive coexceedance for major EU economies on day $t$.

Summary statistics for the coexceedance variables are given in Table 1 . The 2378 days in a sample period are divided into these in which there are no exceedances in any country (e.g. 1558 such days in group of EU accession countries for negative extreme returns), only one country exceedance (e.g. 568 such days in group of EU accession countries for negative extreme returns), and multi country coexceedance (e.g. 252 such days in group of EU accession countries for negative extreme returns). The number of several coexceedances (multi country coexceedance), as well as the number of no coexceedance (no exceedance in any country) is highest in 
the group of major EU economies (in both positive and negative cases) which reflect the higher level of interconnection and stability of this group in comparison with the SEE groups. Both group of SEE countries have more negative than positive coexceedances, while the group accession countries from SEE have more coexceedances than EU member countries from SEE.

\begin{tabular}{lccc}
\hline & \multicolumn{3}{c}{ Number of Coexceedances } \\
& 0 & 1 & $2+$ \\
\hline $\begin{array}{l}\text { Negative Coexceedances in EU accession countries } \\
\text { from SEE (ACC) }\end{array}$ & $1558(65.5 \%)$ & $568(23.9 \%)$ & $252(10.6 \%)$ \\
$\begin{array}{l}\text { Positive Coexceedances in EU accession countries } \\
\text { from SEE (ACC) }\end{array}$ & $1498(63.0 \%)$ & $641(26.9 \%)$ & $239(10.1 \%)$ \\
\hline $\begin{array}{l}\text { Negative Coexceedances in EU member countries } \\
\text { from SEE (EUS) }\end{array}$ & $1615(67.9 \%)$ & $517(21.7 \%)$ & $246(10.4 \%)$ \\
$\begin{array}{l}\text { Positive Coexceedances in EU member countries } \\
\text { from SEE (EUS) }\end{array}$ & $1535(64.6 \%)$ & $595(25.0 \%)$ & $248(10.4 \%)$ \\
\hline $\begin{array}{l}\text { Negative Coexceedances in major EU economies } \\
\text { (MEU) }\end{array}$ & $1969(82.8 \%)$ & $129(5.4 \%)$ & $280(11.8 \%)$ \\
$\begin{array}{l}\text { Positive Coexceedances in major EU economies } \\
\text { (MEU) }\end{array}$ & $1946(82.0 \%)$ & $126(5.3 \%)$ & $303(12.7 \%)$ \\
\hline
\end{tabular}

Table 1. Summary statistics of coexceedance variables

\subsection{Explanatory Variables}

In the empirical analysis, we also use additional explanatory variables in order to estimate the impact of the different stock markets or the economic fundamentals on the coexceedance variable in various multinomial logit models. In the choice of the variables we follow the existing literature, and select to a large extent the same variables as Bae et al. (2003) and Christiansen and Ranaldo (2009). The frequency of all the explanatory variables does correspondents with the daily frequency of the coexceedance variables. The variables are as follows:

- $S_{t}^{U S A}$ : concurrent return from the US stock market (DataStream index).

- $S_{t}^{M E U}$ : concurrent return from the major EU economies stock market (log-returns from equally weighted index constructed for the Germany, United Kingdom, France, Italy and Spain).

- $S_{t}^{E U S}$ : concurrent return from the EU member countries from SEE stock market (log-returns from equally weighted index constructed for the Greece, Slovenia, Romania, Bulgaria and Croatia).

- $\sigma_{t}^{U S A}$ : concurrent volatility for US stock market (square root of the conditional variance stemming from estimating the AR(1)-GARCH(1,1) model for the US stock return - $\left.S_{t}^{U S A}\right)$.

- $\sigma_{t}^{M E U}$ : concurrent volatility for major EU economies stock market (square root of the conditional variance stemming from estimating the AR(1)-GARCH(1,1) model for the major EU economies stock return - $S_{t}^{M E U}$ ).

- $\sigma_{t}^{E U S}$ : concurrent volatility for EU member countries from SEE stock market (square root of the conditional variance stemming from estimating the $\operatorname{AR}(1)-G A R C H(1,1)$ model for the EU member countries from SEE stock return - $S_{t}^{E U S}$ ).

- $C_{t}$ : concurrent currency log return (exchange rate of EUR per USD).

- $\sigma_{t}^{C}$ : concurrent volatility for currency return (square root of the conditional variance stemming from estimating the $\mathrm{AR}(1)-\mathrm{GARCH}(1,1)$ model for the currency log return $\left.-C_{t}\right)$.

- $R_{t}$ : concurrent interest rate (first differences of 1-month EURIBOR).

- $\sigma_{t}^{R}$ : concurrent volatility for currency return (square root of the conditional variance stemming from estimating the $\mathrm{AR}(1)-\mathrm{GARCH}(1,1)$ model for the interest rate $\left.-R_{t}\right)$.

\section{Methodological Framework}

In the first part of the section we present the econometric technique of multinomial logistic regression. In the second part of the section we describe the models used for hypothesis testing.

\subsection{Multinomial Logistic Regression}

We used the Bae et al. (2003) method of multinomial logit model to analyze extreme commovements between stock markets. This method offers a more efficient (in econometric terms) and consistent (in economic terms) way of analyzing commovement between financial markets, because coexceedance measure is not biased in periods of high volatility, it is not restricted to model linear phenomena, and it is easy to compute across time and assets.

Multinomial logit model is appropriate for modeling coexceedance variables, which as discussed above are discrete choice variables that can have only three categories $(0,1$, and 2$)$. We conduct univariate analysis and 
model one coexceedance variable at the time. The probability of, for example, $X N_{t}^{A C C}$ being in category $i$ is given by:

$$
P_{i}=\frac{\exp \left(\boldsymbol{\beta}_{i}^{\prime} \boldsymbol{x}\right)}{\sum_{j=1}^{2} \exp \left(\boldsymbol{\beta}_{i}^{\prime} \boldsymbol{x}\right)}
$$

where $i=1,2 ; \quad \boldsymbol{x}$ is the vector of the explanatory variables (including constant) and $\boldsymbol{\beta}_{i}$ is the vector of coefficients for category $i$. The probability of being in category $i$ is given as a function of explanatory variables $P_{i}=$ function $\left(\boldsymbol{\beta}_{i}^{\prime} \boldsymbol{x}\right)$ where $i=1,2$. There is one coefficient for each covariate for each of the categories (for example, $\beta_{1 j}$ for category 1 for $\left.x_{j}\right)$. The baseline category is $0(i=0)$.

Considering only three categories $(0,1$ and 2$)$, we reduce the number of parameters in the model and make the results easier to understand. The explanation of the coefficients is straightforward: when $\beta_{1 j}$ is significant, then variable $j$ has a positive effect upon the probability of the occurrence of an exceedance; when $\beta_{2 j}$ is significant, then variable $j$ has a significant effect upon the probability of the occurrence of a coexceedance. The significance of a given explanatory variable i.e. whether both coefficients for both categories are insignificant simultaneously $\left(\beta_{1 j}=\beta_{2 j}=0\right.$ for explanatory variable $\left.x_{i}\right)$ is checked with $\chi^{2}$-test. The joint significance of all the explanatory variable is determined by use of $\chi^{2}$-test, where we compare the estimated model with the base line model that only has the constant term as explanatory variable). In addition, we calculate a Cox and Snell's pseudo $R^{2}$ for various models.

The multinomial logit model is estimated in SPSS.

\subsection{Hypotheses and Models}

\section{Persistence effects}

The first hypothesis is about the persistence of the extreme returns in the SEE stock markets. We explore whether negative and positive coexceedances in stock prices are followed by subsequent movements in the same direction (continuation) or in the opposite direction (reversal). The empirical literature has identified both patterns in the developed markets. De Bondt and Thaler (1985) influenced by experimental psychology documentation of the overreaction of the people to unexpected and dramatic news, found reversal pattern in long-term stock return, i.e. stocks with low long-term past returns tend to have higher future returns as the result of the correction of the initial overreaction. Jegadeesh (1990) and (Lehmann, 1990) provide evidence on reversal pattern in short term stock returns. In contrast, Jegadeesh and Titman (1993) and Fama and French (1996) have found continuation pattern of short term stocks returns, i.e. stocks with higher returns tend to have higher future returns.

We use two model forms in order to test the persistence effects in SEE stock markets. The first form of the model test whether the coexceedances in EU member countries from SEE group stock markets are autoregressive and whether they are related to the coexceedances of the same type in major EU economies group stock markets. So, for the negative coexceedance variable for the EU member countries from SEE $\left(X N_{t}^{E U S}\right)$ the explanatory variables are $X N_{t-1}^{E U S}$ and $X N_{t}^{M E U}$. For $X N_{t}^{E U S}$ the probability of having $i$ negative coexceedances is:

$$
\text { For } X N_{t}^{E U S}: P_{i}=\text { function }\left(\beta_{i 0}+\beta_{i 1} X N_{t-1}^{E U S}+\beta_{i 2} X N_{t}^{M E U}\right) \text { where } i=1,2 \text {. }
$$

The model form is similar for the positive coexceedance variable, where explanatory variables are $X P_{t-1}^{E U S}$ and $X P_{t}^{M E U}$. The second form of the model test whether the coexceedances in EU accession countries from SEE group stock markets are autoregressive and whether they are related to the coexceedances of the same type in EU member countries from SEE and major EU economies group stock markets. We think that transitory effect of the integrated markets in the EU from the SEE is important in modeling of the coexceedanes of accession countries. So, for the negative coexceedance variable for the EU accession countries from SEE $\left(X N_{t}^{A C C}\right)$ the explanatory variables are $X N_{t-1}^{A C C}, X N_{t}^{E U S}$ and $X N_{t}^{M E U}$. For $X N_{t}^{A C C}$ the probability of having $i$ negative coexceedances is:

$$
\begin{aligned}
& \text { For } X N_{t}^{A C C}: P_{i}=\text { function }\left(\beta_{i 0}+\beta_{i 1} X N_{t-1}^{A C C}+\beta_{i 2} X N_{t}^{E U S}+\beta_{i 3} X N_{t}^{M E U}\right) \text { where } i=1,2 . \\
& \text { Asset class effects }
\end{aligned}
$$

The second hypothesis is about the asset class effects on the extreme returns in the SEE stock markets. We explore whether currency rate and interest rates movements, as well as American and European stock markets developments, are relevant for explaining coexccedances in SEE stock markets. Obstfeld (1986) and Morris and Shin (1998) suggested currency attacks as important source of extreme returns transmission, while funding liquidity and market liquidity is pointed out by Brunnermeier and Pedersen (2009). Moreover, Caballero and Krishnamurthy (2008) put a light to flight to quality episodes (substitution between equities and safer assets such as bonds or money) as important source of financial instability. In addition, Christiansen and Ranaldo (2009) 
argue that EU membership may have decreased the currency risk premium and increased the degree of stock return correlation within new member states and between them and old member states.

As in the case of persistence effects, we use two model forms in order to test the asset class effects in SEE stock markets. The first form of the model test whether the coexceedances in EU member countries from SEE group stock markets are related to different assets type returns. The explanatory variables are: currency return $\left(C_{t}\right)$, interest rate $\left(R_{t}\right)$, major EU stock market return $\left(S_{t}^{M E U}\right)$ and US stock market return $\left(S_{t}^{U S A}\right)$. So, for the negative coexceedance variable $\left(X N_{t}^{E U S}\right)$ the probability of having $i$ negative coexceedances is:

$$
\text { For } X N_{t}^{E U S}: P_{i}=\text { function }\left(\beta_{i 0}+\beta_{i 1} C_{t}+\beta_{i 2} R_{t}+\beta_{i 3} S_{t}^{M E U}+\beta_{i 4} S_{t}^{U S A}\right) \text { where } i=1,2 \text {. }
$$

The model form is identical in the case of positive coexceedances in EU member countries from SEE $\left(X P_{t}^{E U S}\right)$. The second form of the model designed for EU accession countries from SEE stock markets have additional variable EU member countries for SEE stock market return $\left(S_{t}^{E U S}\right)$, in order to be captured regional transitory effect. So, for the negative coexceedance variable $\left(X N_{t}^{A C C}\right)$ the probability of having $i$ negative coexceedances is:

$$
\begin{aligned}
& \text { For } X N_{t}^{A C C}: P_{i}=\text { function }\left(\beta_{i 0}+\beta_{i 1} C_{t}+\beta_{i 2} R_{t}+\beta_{i 3} S_{t}^{E U S}+\beta_{i 4} S_{t}^{M E U}+\beta_{i 5} S_{t}^{U S A}\right) \text { where } i=1,2 . \\
& \text { Volatility effects }
\end{aligned}
$$

The third hypothesis is about the volatility effects on the extreme returns in the SEE stock markets. We explore whether coexceedanes are more likely to occur in highly volatile environment overriding all asset classes. Leveraged international allocations may also increase extreme events propagation. Schinasi and Smith (2001) show that even in an efficient and frictionless setting, spillover effects can emerge on the basis of optimal portfolio decisions taken by leveraged investors as a simple rebalancing response.

We use two different model forms in order to test the asset class effects in SEE stock markets. The first form of the model test whether the coexceedances in EU member countries from SEE group stock markets are related to volatility of different assets type returns. The explanatory variables are: volatility of currency return $\left(\sigma_{t}^{C}\right)$, volatility of interest rate $\left(\sigma_{t}^{R}\right)$, volatility of major EU stock market return $\left(\sigma_{t}^{M E U}\right)$ and volatility of US stock market return $\left(\sigma_{t}^{U S A}\right)$. So, for the negative coexceedance variable $\left(X N_{t}^{E U S}\right)$ the probability of having $i$ negative coexceedances is:

$$
\text { For } X N_{t}^{E U S}: P_{i}=\text { function }\left(\beta_{i 0}+\beta_{i 1} \sigma_{t}^{C}+\beta_{i 2} \sigma_{t}^{R}+\beta_{i 3} \sigma_{t}^{M E U}+\beta_{i 4} \sigma_{t}^{U S A}\right) \text { where } i=1,2
$$

The model form is identical in the case of positive coexceedances in EU member countries from SEE $\left(X P_{t}^{E U S}\right)$. The second form of the model designed for EU accession countries from SEE stock markets have additional variable EU member countries for volatility of SEE stock market return $\left(\sigma_{t}^{E U S}\right)$, in order to be captured regional transitory effect. So, for the negative coexceedance variable $\left(X N_{t}^{A C C}\right)$ the probability of having $i$ negative coexceedances is:

$$
\text { For } X N_{t}^{A C C}: P_{i}=\text { function }\left(\beta_{i 0}+\beta_{i 1} \sigma_{t}^{C}+\beta_{i 2} \sigma_{t}^{R}+\beta_{i 3} \sigma_{t}^{M E U}+\beta_{i 4} \sigma_{t}^{U S A}+\beta_{i 5} \sigma_{t}^{E U S}\right) \text { where } i=1,2 \text {. }
$$

\section{Empirical Results}

Table 2 reports the estimation results of the multinomial logit model for the four different coexceedance variables. The left-most part of the table concerns the situation where the negative coexceedance variable for the EU members from SEE is the explained variable, in the second part the positive coexceedance variable for the EU members from SEE is the explained variable, and in the third and fourth parts the negative and positive coexceedances for EU accession countries from SEE are the explained variables. The first two columns show the parameter estimates and their standard deviations in parenthesis. In the third column, $* / * * * * * *$ indicate the significance of the individual parameter $\left(\beta_{\mathrm{ij}}\right)$ at a $10 \% / 5 \% / 1 \%$ level of significance. In the fourth column, it is marked by $\& / \& \& / \& \& \&$ when the explanatory variable $\mathrm{x}_{\mathrm{j}}$ is overall significant at the $10 \% / 5 \% / 1 \%$ level of significance $\left(\beta_{1 \mathrm{j}}=\beta_{2 \mathrm{j}}=0\right)$. We include an intercept dummy, as well as interaction dummies for the explanatory variables in the model, where the dummy variable takes value 1 after January 1, 2007 and zero before. The estimates are not tabulated, but the joint significance level $(10 \% / 5 \% / 1 \%)$ of the dummies variables is indicated by \#/\#\#/\#\#\# in the fifth column in the every of the fourth parts of the table.

The table 2 reports the persistence effects results. The estimated significant and positive lagged explanatory variable in all four models is evidence in favor of the continuation hypothesis (subsequent movements in the same direction) in the SEE markets rather than reversal hypothesis (subsequent movements in the opposite direction). It implies that the number of extreme negative returns today is positively related to the number of extreme negative returns yesterday in the both SEE groups. Or, that the number of extreme positive returns today is positively related to the number of extreme positive returns yesterday in both SEE groups.

Regarding extreme returns in major EU economies markets as explanatory variable, we found them significant and positive in the two models of EU member states from SEE. It means that the more extreme negative returns 
we have on major EU countries stock markets, the more likely is to have many extreme negative returns on the EU member states from SEE stock markets. On contrary, the extreme returns in major EU economies stock markets are not significant in the model of negative coexceedance for accession countries from SEE, while it is significant only on $10 \%$ level for the extreme positive coexceedance of the same group. For the model of negative coexceedance for accession countries from SEE, the additional explanatory variable - negative coexceedance for EU member states from SEE is significant and positive. It implies that the extreme negative influence of major EU countries stock markets on the extreme negative returns of the accession countries is not directly, but through the EU member states from SEE stock markets. However, this is not true for the extreme positive returns of the accession group. The positive coexceedance of accession group is not influenced by positive coexceedance of EU member states group, but only from positive coexceedances from major EU economies group. It means that in accession group stock markets bad signals comes from the region, while good signals from the major EU economies.

The results for the asset class effects are given in the table 3. For the EU member countries from SEE, the likelihood of observing negative coexceedances is only related to major EU economies stock market return. In particular, it is negatively related to stock returns in major EU economies market. For the positive coexceedance variable for EU member countries from SEE both the major EU economies stock return and the currency return have significant effects, but on the $10 \%$ level. The effect of major EU economies stock return is positive, while the effect of the exchange rate of EUR per USD is negative. In both cases (negative or positive coexceedance variable) for EU member countries from SEE the interest rate or US stock market return are not of importance.

The likelihood of observing negative coexceedances in EU accession countries from SEE appear more highly connected with EU member states from SEE stock returns than with major EU economies stock return. These links have negative effects upon the likelihood. Also, there is positive link with interest rates, but to lesser extent. The positive coexceedance variable for EU accession countries from SEE seems to be almost not connected with the observed variables, with the exception of the weak link with the US stock market return.

\begin{tabular}{|c|c|c|c|c|c|c|c|c|c|c|}
\hline & EU memb & rs fron & & & & & & & & \\
\hline & Negative & & & & & Positive & & & & \\
\hline Constant (1) & -1.78 & 0.13 & $* * *$ & $\& \& \&$ & \#\#\# & -1.25 & 0.12 & $* * *$ & $\& \& \&$ & \\
\hline Constant (2) & -3.85 & 0.32 & $* * *$ & & & -2.89 & 0.24 & $* * *$ & & \\
\hline$X N_{t-1}^{E U S}$ & 0.75 & 0.20 & $* * *$ & $\& \& \&$ & $\#$ & & & & & \\
\hline$X N_{t-1}^{E U S}(2)$ & 1.22 & 0.34 & $* * *$ & & & & & & & \\
\hline$X P_{t-1}^{E U S}$ & & & & & & 0.52 & 0.15 & $* * *$ & $\& \& \&$ & \#\# \\
\hline$X P_{t-1}^{E U S}(2)$ & & & & & & 1.00 & 0.23 & $* * *$ & & \\
\hline$X N_{t}^{M E U}$ & 0.80 & 0.27 & $* * *$ & $\& \& \&$ & & & & & & \\
\hline$X N_{t}^{M E U}(2)$ & 1.36 & 0.35 & $* * *$ & & & & & & & \\
\hline$X P_{t}^{M E U}$ & & & & & & -0.07 & 0.29 & & $\& \&$ & \\
\hline$X P_{t}^{M E U}(2)$ & & & & & & 0.79 & 0.28 & $* * *$ & & \\
\hline Pseudo $R^{2}$ & $14.6 \%$ & & & & & $7.90 \%$ & & & & \\
\hline Chi-square & $374.2 * * *$ & & & & & $195.6^{* * *}$ & & & & \\
\hline
\end{tabular}

\begin{tabular}{|c|c|c|c|c|c|c|c|c|c|c|}
\hline & Accessior & countr & from & & & & & & & \\
\hline & Negative & & & & & Positive & & & & \\
\hline Constant (1) & -1.28 & 0.13 & $* * *$ & $\& \& \&$ & \#\# & -0.81 & 0.13 & $* * *$ & $\& \& \&$ & \#\#\# \\
\hline Constant (2) & -3.57 & 0.32 & $* * *$ & & & -2.55 & 0.25 & $* * *$ & & \\
\hline$X N_{t-1}^{A C C}$ & 0.28 & 0.17 & * & $\& \& \&$ & & & & & & \\
\hline$X N_{t-1}^{A C C}$ & 0.95 & 0.30 & $* * *$ & & & & & & & \\
\hline$X P_{t-1}^{A C C}$ & & & & & & 0.67 & 0.14 & $* * *$ & $\& \& \&$ & \#\# \\
\hline$X P_{t-1}^{A C C}(2)$ & & & & & & 1.19 & 0.21 & $* * *$ & & \\
\hline$X N_{t}^{E U S}(1)$ & 0.74 & 0.19 & $* * *$ & $\& \& \&$ & & & & & & \\
\hline$X N_{t}^{E U S}(2)$ & 1.23 & 0.32 & $* * *$ & & & & & & & \\
\hline$X P_{t}^{E U S}$ & & & & & & -0.02 & 0.15 & & & \\
\hline$X P_{t}^{E U S}$ (2) & & & & & & 0.27 & 0.22 & & & \\
\hline$X N_{t}^{M E U}$ & 0.44 & 0.25 & $*$ & & & & & & & \\
\hline$X N_{t}^{M E U}$ (2) & -0.26 & 0.58 & & & & & & & & \\
\hline$X P_{t}^{M E U}$ & & & & & & 0.47 & 0.24 & $* *$ & $\&$ & \\
\hline$X P_{t}^{M E U}(2)$ & & & & & & -0.19 & 0.49 & & & \\
\hline Pseudo $R^{2}$ & $16.7 \%$ & & & & & $14.1 \%$ & & & & \\
\hline Chi-square & $435.1 * * *$ & & & & & $362.2 * * *$ & & & & \\
\hline
\end{tabular}




\begin{tabular}{|c|c|c|c|c|c|c|c|c|c|c|c|}
\hline \multirow[b]{3}{*}{ Constant (1) } & \multicolumn{11}{|c|}{ EU members from SEE } \\
\hline & \multicolumn{5}{|c|}{ Negative } & \multicolumn{4}{|c|}{ Positive } & & \\
\hline & -1.48 & 0.12 & $* * *$ & $\& \& \&$ & \#\#\# & \multicolumn{2}{|l|}{-1.02} & 0.10 & $* * *$ & \multicolumn{2}{|c|}{$\& \& \&$} \\
\hline Constant (2) & -3.28 & 0.26 & $* * *$ & & & \multicolumn{2}{|l|}{-2.44} & 0.20 & $* * *$ & & \\
\hline$C_{t}(1)$ & 0.24 & 0.21 & & & & \multicolumn{2}{|l|}{0.09} & 0.19 & \multirow[b]{2}{*}{$* *$} & $\&$ & \# \\
\hline$C_{t}(2)$ & 0.01 & 0.44 & & & & \multicolumn{2}{|l|}{-0.66} & 0.31 & & & \\
\hline$R_{t}(1)$ & -0.02 & 0.14 & & & & \multicolumn{2}{|l|}{-0.10} & 0.13 & & & \\
\hline$R_{t}(2)$ & 0.20 & 0.22 & & & & \multicolumn{2}{|l|}{-0.37} & 0.23 & & & \\
\hline $\mathrm{S}_{\mathrm{t}}^{\mathrm{USA}}(1)$ & 0.21 & 0.20 & & & & \multicolumn{2}{|l|}{-0.21} & 0.18 & & & \\
\hline$S_{t}^{U S A}(2)$ & 0.27 & 0.41 & & & & \multicolumn{2}{|l|}{0.26} & 0.30 & & & \\
\hline$S_{t}^{M E U}(1)$ & -0.53 & 0.19 & $* * *$ & $\& \& \&$ & & \multicolumn{2}{|l|}{-0.07} & 0.18 & & $\&$ & \# \\
\hline$S_{t}^{M E U}(2)$ & -0.97 & 0.33 & $* * *$ & & & \multicolumn{2}{|l|}{0.72} & 0.32 & $* *$ & & \\
\hline Pseudo $R^{2}$ & $14.2 \%$ & & & & & $10.5 \%$ & & & & & \\
\hline Chi-square & $365.6^{\prime}$ & & & & & $262.6^{*}$ & & & & & \\
\hline & Access & ountries & om SE & & & & & & & & \\
\hline & Negati & & & & & Positive & & & & & \\
\hline Constant (1) & -0.91 & 0.11 & $* * *$ & $\& \& \&$ & \#\#\# & -0.45 & 0.10 & $* * *$ & $\& \& \&$ & & \#\#\# \\
\hline Constant (2) & -2.62 & 0.22 & $* * *$ & & & -1.73 & 0.16 & $* * *$ & & & \\
\hline$C_{t}(1)$ & -0.12 & 0.19 & & & & -0.01 & 0.17 & & & & \\
\hline$C_{t}(2)$ & 0.40 & 0.40 & & & & -0.11 & 0.27 & & & & \\
\hline$R_{t}(1)$ & 0.20 & 0.11 & $*$ & $\&$ & \# & 0.10 & 0.11 & & & & \\
\hline$R_{t}(2)$ & -0.37 & 0.29 & & & & 0.06 & 0.17 & & & & \\
\hline $\mathrm{S}_{\mathrm{t}}^{\mathrm{USA}}(1)$ & 0.19 & 0.18 & & & & 0.10 & 0.17 & & & & \\
\hline$S_{t}^{U S A}(2)$ & 0.05 & 0.37 & & & & -0.48 & 0.26 & $*$ & $\&$ & & \\
\hline$S_{t}^{M E U}(1)$ & -0.45 & 0.18 & $* *$ & $\& \&$ & & 0.12 & 0.16 & & & & \\
\hline$S_{t}^{M E U}(2)$ & -0.20 & 0.35 & & & & 0.30 & 0.27 & & & & \\
\hline$S_{t}^{E U S}(1)$ & -0.96 & 0.19 & $* * *$ & $\& \& \&$ & \#\#\# & -0.10 & 0.16 & & & & \# \\
\hline$S_{t}^{E U S}(2)$ & -1.50 & 0.34 & $* * *$ & & & 0.07 & 0.25 & & & & \\
\hline Pseudo $R^{2}$ & $11.7 \%$ & & & & & $6.4 \%$ & & & & & \\
\hline Chi-square & $295.5 *$ & & & & & $157.9 * * *$ & & & & & \\
\hline
\end{tabular}

Table 3. Asset class effects

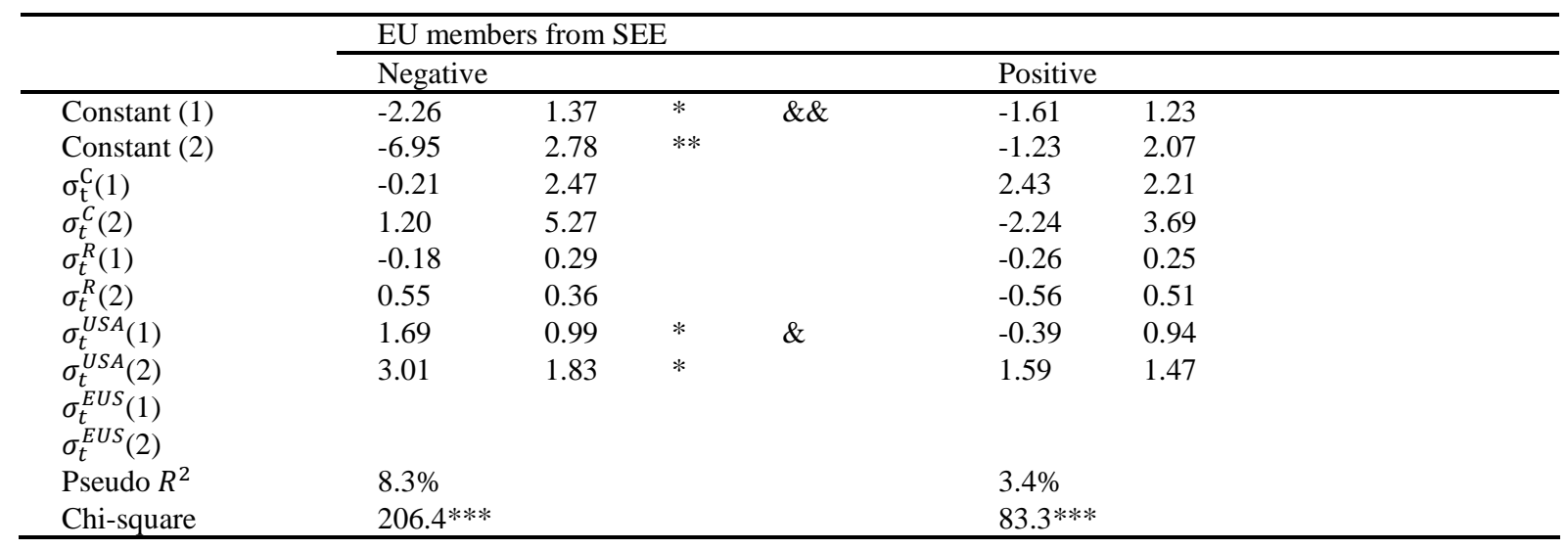

\begin{tabular}{|c|c|c|c|c|c|c|c|c|c|c|}
\hline \multirow[b]{3}{*}{ Constant (1) } & \multicolumn{10}{|c|}{ Accession countries from SEE } \\
\hline & \multicolumn{5}{|c|}{ Negative } & \multicolumn{5}{|c|}{ Positive } \\
\hline & -1.55 & 1.13 & & & & -2.97 & 1.12 & $* * *$ & $\& \&$ & \\
\hline Constant (2) & -1.07 & 2.94 & & & & -1.56 & 2.27 & & & \\
\hline$\sigma_{\mathrm{t}}^{\mathrm{C}}(1)$ & -3.90 & 2.13 & & & & -0.50 & 2.06 & & & \\
\hline$\sigma_{t}^{C}(2)$ & -5.05 & 4.83 & & & & 0.87 & 3.50 & & & \\
\hline$\sigma_{t}^{R}(1)$ & 0.25 & 0.21 & & & & -0.27 & 0.22 & & $\& \& \&$ & \#\#\# \\
\hline$\sigma_{t}^{R}(2)$ & -1.18 & 0.94 & & & & -1.95 & 0.80 & $* * *$ & & \\
\hline$\sigma_{t}^{U S A}(1)$ & 1.50 & 0.92 & & & & 3.15 & 0.91 & $* * *$ & $\& \& \&$ & \#\#\# \\
\hline$\sigma_{t}^{U S A}(2)$ & 1.54 & 1.92 & & & & 1.18 & 1.47 & & & \\
\hline$\sigma_{t}^{E U S}(1)$ & 1.85 & 0.65 & $* * *$ & $\& \& \&$ & $\# \#$ & 0.88 & 0.66 & & $\& \& \&$ & \\
\hline$\sigma_{t}^{E U S}(2)$ & 3.05 & 1.19 & $* *$ & & & 3.00 & 0.88 & $* * *$ & & \\
\hline Pseudo $R^{2}$ & $9.7 \%$ & & & & & $6.0 \%$ & & & & \\
\hline Chi-square & $241.5^{*}$ & & & & & $146.4^{\prime}$ & & & & \\
\hline
\end{tabular}

Table 4. Volatility effects 
The results for volatility effects are given in table 4. For the negative coexceedance variable for EU members countries from SEE, we find only stock markets returns volatility significant, whereas the exchange rate volatility and interest rate volatility is insignificant. The US stock market return volatility and in major EU economies stock market volatility increase the likelihood of negative coexceedance. The positive coexceedance variable for EU member countries from SEE it is not related with any observed asset class volatility.

For the EU accession countries from SEE, the volatility in all three stock markets (US, major EU economies and EU members from SEE) is relevant for likelihood of observing coexceedances. In both negative or positive coexceedances models the increase in volatility in US stock market or EU members from SEE stock market leads to increase of the likelihood of observing a coexceedances in EU accession stock markets. In addition, for the accession countries negative coexceedances, there is weak link with exchange rate volatility and for positive coexceedances with interest rate volatility.

\section{Conclusion}

We apply the coexceedance methodology of Bae et al. (2003) to investigate the co-movements in the extreme returns between SEE stock markets. We divide the SEE stock markets on two groups based on country's EU membership in order to allow for transmission mechanism from major EU economies stock markets to EU member countries from SEE, and in addition, transitory effect from EU member countries from SEE to accession countries from SEE region. The negative coexceedance variable for the EU accession countries from SEE counts the number of extreme returns (bellow $10 \%$ percentile) across the EU accession countries on a given day. The positive coexceedance variable for the EU accession countries from SEE counts the number of extreme returns (above $90 \%$ percentile) across the EU accession countries on a given day. The negative coexceedance variables and positive coexceedances variables for the EU member countries from SEE and major EU economies are constructed analogously. Using the multivariate logit model, we test the persistence, asset class and volatility effects on the likelihood of the coexceedances in both SEE groups.

We find evidence in support of continuation hypothesis for the extreme negative and positive stock returns in the both SEE groups (EU member states and EU accession countries). The coexceedances in EU member countries from SEE stock markets are influenced by the coexceedances in major EU economies stock markets, while in the case of EU accession countries from SEE stock markets this influence is much weaker and present only for positive coexceedances. However, negative coexceedances of accession countries from SEE are influenced by negative coexceedances from EU member countries from SEE stock markets, which imply that in the accession group stock markets bad signals comes from region, while good signals comes from the major EU economies. In respect to asset class effects and volatility effects, the results suggest that later have more influence on extreme coexceedance on the SEE stock markets than the former. The volatility of the US stock markets is important in determination of the extreme returns comovement in the both group of SEE markets, while for the accession group additionally volatility of the EU member countries from SEE is important.

\section{References}

- Adjaoute, K., \& Danthine, J.-P. (2003). Integration and Equity Returns: A Theory-Based Assesment. FAME Research Paper, no. 84 .

- $\quad$ Babetskii, I., Komarek, L., \& Komarkova, Z. (2007). Financial Integration of Stock Markets among New EU Member States and the Euro Area. Czech Journal of Economics and Finance, 57(7-8), 341-362.

- Bae, K.-H., Karolyi, A. G., \& Stulz, R. M. (2003). A New Approach to Measuring Financial Contagion. The Review of Financial Studies, 16(3), 718-763.

- Bekaert, G., \& Harvey, C. (1995). Time-Varying World Market Integration. Journal of Finance, 50(2), 403444.

- $\quad$ Brunnermeier, M. K., \& Pedersen, L. H. (2009). Market Liquidity and Funding Liquidity. The Review of Financial Studies, 22(6), 2201-2238.

- Caballero, R. J., \& Krishnamurthy, A. (2008). Collective Risk Management in a Flight to Quality Episode. The Journal of Finance, 63(5), 2195-2230.

- Cappieollo, L., Gerard, B., Kadareja, A., \& Manganelli, S. (2006). Financial Integration of New EU Member States. European Central Bank Working Paper No. 683.

- Cerny, A., \& Koblas, M. (2008). Stock Market Integration and the Speed of Information Transmission. Czech Journal of Economics and Finance, 58(1-2), 2-20.

- Christiansen, C., \& Ranaldo, A. (2009). Extreme coexceedances in new EU member states' stock returns. Journal of Banking and Finance (33), 1048-1057. 
- $\quad$ Dajcman, S., Festic, M., \& Kavkler, A. (2012). Comovement Dynamics between Central and Aestern European and Developed European Stock Markets during Integration and Amid Financial Crises - A Wavelet Analysis. Enineering Economics, 23(1), 22-32.

- De Bondt, W., \& Thaler, R. (1985). Does the Stock Market Overreact? The Journal of Finance, 40(3), 793805.

- Egert, B., \& Kocenda, E. (2007). Interdependencs between Eastern and Western European stock markets: Evidence from intraday data. Economic Systems, 31(2), 184-203.

- Engle, R., \& Susmel, R. (1993). Common volatility in international equity markets. Journal of Business and Economic Statistics, 11(2), 167-176.

- $\quad$ Erjavec, N., \& Cota, B. (2007). Modeling Stock Market Volatility in Croatia. Ekonomska istrazivanja, 20(1).

- $\quad$ Fama, E., \& French, K. (1996). Multifactor Explanations of Asset Pricing Anomalies. The Journal of Finance, 51(1), 55-84.

- Forbes, K., \& Rigobon, R. (2002). No contagion, Only Interdependence: Measuring Stock Market Comovements. Journal of Finance, 2223-2261.

- French, K. R., Schwert, W., \& Stambaugh, R. F. (1987). Expected Stock Returns and Volatility. Journal of Financial Economics, 19, 3-29.

- Gilmore, C., Lucey, B., \& McManus, G. (2008). The Dynamics of Central European Equity Market Integration. Quarterly Review of Economics and Finance, 48(3), 605-622.

- Gradojevic, N., \& Dobardzic, E. (2012). Causality between Regional Stock Markets: A Frequency Domain Approach. Panoeconomicus, 5, 633-647.

- Horvath, R., \& Petrovski, D. (2013). International Stock market integration: Central and South Eastern Europe compared. IOS Working Paper, No.317.

- Jegadeesh, N. (1990). Evidence of Predictable Behavior of Security Returns. The Journal of Finance, 45(3), 881-898.

- Jegadeesh, N., \& Titman, S. (1993). Returns to Buying Winners and Selling Losers: Implications for Stock Market Efficiency. The Jounrnal of Finance, 48(1), 65-91.

- Johnson, R., \& Soenen, L. (2003). Economic integration and stock market comovements in the Americas. Journal of Multinationonal Financial Management, 13(1), 85-100.

- Kasch-Haroutounian, M., \& Price, S. (2001). Volatility in the Transition Markets of Central Europe. Applied Financial Economics, 11(1), 93-105.

- Kenourgios, D., \& Samitas, A. (2011). Equity market integration in emerging Balkan markets. Research in International Business and Finance, 25(3), 296-307.

- Kocenda, E., \& Egert, B. (2011). Time-Varying Synchronization of European Stock Markets. Empirical Economics, 40(2), 393-407.

- Lampe, J. (2005). Balkans into Southeastern Europe. Palgrave Macmillan.

- Lehmann, B. N. (1990). Fads, Martingales, and Market Efficiency. The Quarterly Journal of Economics, 105(1), 1-28.

- Longin, F., \& Solnik, B. (1995). Is the correlation in international equity returns constant: 1960-1990? Journal of International Money and Finance, 14(1), 3-26.

- Markwat, T., Kole, E., \& van Dijk, D. (2009). Contagion as a domino effect in global stock markets. Journal of Banking and Finance (33), 1996-2012.

- Morris, S., \& Shin, H. S. (1998). Unique Equilibrium in a Model of Self-Fulfilling Currency Attacks. The American Economic Review, 88(3), 587-597.

- Obstfeld, M. (1986). Rational and Self-Fulfilling Balance-of-Payments Crises. The American Economic Revie, 76(1), 72-81.

- Schinasi, G., \& Smith, R. (2001). Portfolio diversificatio, leverage, and financial contagion. In S. Claessens, \& K. Forbes, International Financial Contagion (pp. 187-223). Boston, MA: Kluwer Academic Publishers.

- Vizek, M., \& Dadic, T. (2006). Integration of Croatian, CEE and EU Equity Markets: Cointegration Approach. Ekonomski pregled, 57(9-10), 631-646.

- Voronkova, S. (2004). Equity market integration in Central European emerging markets: A cointegration analysis with shifting regimes. International Review of Financial Analysis, 13(5), 633-647. 